\title{
Raw material safety as one of the factors of sustainable development of the food industry
}

\author{
Aleksandr Arisov ${ }^{1, *}$, Artem Leyvy ${ }^{2}$, Ekaterina Kryukova ${ }^{1}$, Natalia Zavorokhina $^{1}$ and \\ Ekaterina Pastushkova ${ }^{1}$ \\ ${ }^{1}$ Ural State University of Economic, 8 March street, 62, 620144 Yekaterinburg, Russia \\ ${ }^{2}$ South Ural State University, Lenin avenue, 76, 454080 Chelyabinsk, Russia
}

\begin{abstract}
One of the trends in the development of the public catering market in the Ural region is the emergence of new "players", which leads to increased competition. The use of crushed sprouted grain in public catering products can increase the competitiveness of enterprises, because in the field of public catering, the trend towards healthy eating continues, one of the directions of which is grain germination. The seeds germinate in a humid environment. They have a high content of carbohydrates (in particular starch) and are not always under the lights, which contributes to the reproduction of microorganisms. To suppress the growth of the number of microorganisms, it is proposed to use cold plasma radiation. Such a nonthermal physical effect will reduce the microbiological parameters of raw materials without affecting the physical and chemical processes during germination of the sprout. The optimal value of settings at which the required level of microbiological contamination is achieved has been determined. With increasing exposure, microbiological parameters change slightly, while the cost of processing increases.
\end{abstract}

\section{Introduction}

Over the past few years in Russia, import substitution in the food industry has been one of the main directions of development. It has great potential in the creation of technologies that will allow the production of products already existing on the market, but with a higher quality [1].

One of the trends in the development of the public catering market in the Ural region is the emergence of new "players". The development of the region attracts representatives of the catering sector of the regional, all-Russian, and even world level. It causes an increase in competition and an improvement in the quality of the goods and services provided [2].

Modern trends can be used to improve the competitiveness of enterprises. One of them is healthy eating. Currently, more and more catering establishments are opening, aiming at this specialization. Grain sprouting is often used to ensure a healthy diet. Growth of sprout forms vitamin $\mathrm{C}$ and activates the amylolytic effect, which acts on starch [3, 4].

${ }^{*}$ Corresponding author: arisov_av@usue.ru 
Grains contain a lot of carbohydrates (including starch), germinate in a humid and not always lit environment. This promotes the multiplication of microorganisms. Various physical, chemical and biological methods can be used to suppress microorganisms

It is proposed to reduce their number to the stage of germination, because the germination environment is favorable for the reproduction of microorganisms. It is also necessary to minimize the impact on the grain itself, because some changes can negatively affect growth of sprout and the physicochemical processes inside the grain during germination. Non-thermal physical methods are suitable for these parameters.

Promising physical non-thermal methods of disinfection of plant raw materials used in world practice are presented in table 1.

Table 1. Physical non-thermal methods of disinfection of plant materials [5-7].

\begin{tabular}{|l|l|l|}
\hline \multicolumn{1}{|c|}{ Methods } & \multicolumn{1}{|c|}{ Variable processing parameters } & Mechanism of action \\
\hline $\begin{array}{l}\text { Pulsed electric } \\
\text { field }\end{array}$ & $\begin{array}{l}\text { Electric field strength; time of processing; shape, } \\
\text { width, frequency and polarity of pulses }\end{array}$ & Electroporation \\
\hline $\begin{array}{l}\text { Ultrasonic } \\
\text { exposure }\end{array}$ & Frequency; power; time of processing & Cavitation \\
\hline $\begin{array}{l}\text { Ultraviolet } \\
\text { exposure }\end{array}$ & Power; wavelength; time of processing & $\begin{array}{l}\text { Disruption of the } \\
\text { cytoplasmic } \\
\text { membrane }\end{array}$ \\
\hline $\begin{array}{l}\text { Cold Plasma } \\
\text { Radiation (CPR) }\end{array}$ & $\begin{array}{l}\text { Electric field; gas supply (pressure, type, flow } \\
\text { rate, frequency); exposure time; used } \\
\text { environment }\end{array}$ & $\begin{array}{l}\text { Degradation of } \\
\text { proteins, lipids in } \\
\text { DNA+apoptosis }\end{array}$ \\
\hline
\end{tabular}

This paper discusses the impact of CPR. It is a relatively young method with few studies. Also, research of the South Ural State University on wheat processing $[8,9]$ show that the optimal solution to the problem is the use of CPR for the given parameters (voltage $10 \mathrm{kV}$, frequency $50 \mathrm{~Hz}$, exposure 10) among non-thermal physical methods.

\section{Objects and research methods}

Research objects:

1) Hull-grained oats for germination (TU 10.61.33-010-0200792814, IE Rashkovetskiy M.A., Krasnodar);

2) Selected wheat for germination (TU 9700-001-92557466-11, LLC "All for the benefit", Moscow);

3) Winter rye for germination (TU 01.11.00-002-38744625-2016, LLC "Way of Life", Khabarovsk);

4) Hull-grained barley for germination (TU 9700-001-92557466-11, LLC "All for the benefit", Moscow).

The work uses the CPR grain processing unit, developed at the South Ural State University, developer - LeyvyA.Ya., patent for invention No. 2707944 "Method of grain disinfection". CPR generation was carried out due to a negative corona discharge at a pulsed voltage with the following parameters: voltage $10 \mathrm{kV}$, frequency $50 \mathrm{~Hz}$, air acts as a plasma-forming substance under normal conditions. Variable parameter - exposure, min.

Test samples:

- Sample No. o-0 - control oats;

- Sample No. w-0 - wheat control;

- Sample No. r- 0 - rye control;

- Sample No. b-0 - barley control;

- Sample No. o-1 - CPR processed oats, exposure $5 \mathrm{~min}$;

- Sample No. o-2 - CPR processed oats, exposure $10 \mathrm{~min}$; 
- Sample No. o-3 - CPR processed oats, exposure $15 \mathrm{~min}$;

- Sample No. w-1 - CPR processedwheat, exposure 10 min;

- Sample No. r-1 - CPR processedrye, exposure $10 \mathrm{~min}$;

- Sample No. b-1 - CPR processedbarley, exposure $10 \mathrm{~min}$.

Methods for determining microbiological indicators: GOST 10444.14, GOST 10444.15, GOST 31747.

\section{Analysis of the effect of cold plasma radiation on microbiological parameters of grain}

Research has been carried out on the effect of processing grain for germination of CPR to reduce microbiological parameters to acceptable levels. At the first stage, research of the influence of CPR on the indicators of oat grain were carried out. The treatment was carried out at a voltage of $10 \mathrm{kV}$, a frequency of $50 \mathrm{~Hz}$ and an exposure of 5, 10 and 15 minutes.

Microbiological indicators of oat samples are presented in table 2.

Table 2. Microbiological indicators of oat samples (0-0 - permissible level according to TR CU 021/2011)

\begin{tabular}{|l|c|c|c|c|}
\hline \multirow{2}{*}{ Samples } & \multicolumn{3}{|c|}{ Defined indicators } \\
\cline { 2 - 5 } & QMAFAnM, CFU/g & Colibacillus group & Mold, CFU/g & $\begin{array}{c}\text { Yeast, } \\
\text { CFU/g }\end{array}$ \\
\hline $0-0$ & $<5,0 \times 10^{3}$ & not allowed in 0.1 g & $<50$ & $<100$ \\
\hline o-0 & $1,5 \times 10^{5}$ & detected in $0.01 \mathrm{~g}$ & $<100$ & 100 \\
\hline o-1 & $5,4 \times 10^{3}$ & not detected in $0.1 \mathrm{~g}$ & 20 & 20 \\
\hline o-2 & $2,6 \times 10^{3}$ & not detected in $0.1 \mathrm{~g}$ & $<10$ & $<10$ \\
\hline o-3 & $2,5 \times 10^{3}$ & not detected in $0.1 \mathrm{~g}$ & $<10$ & $<10$ \\
\hline
\end{tabular}

QMAFAnM is reduced by a factor of 27 when processing CPR with an exposure of 5 minutes, but the value remains above the permissible value. QMAFAnM decreases by 2 times at an exposure of 10 minutes, if compared with the indicator at an exposure of 5 minutes. A further increase in exposure does not significantly affect the performance, while increasing the processing cost.

Additionally, research have been carried out on CPR processing of wheat, rye and barley grains. For the research, the same parameters were used at which the oat grain was processed (voltage $10 \mathrm{kV}$, frequency $50 \mathrm{~Hz}$ and exposure $10 \mathrm{~min}$.). Microbiological indicators of wheat, rye and barley samples are presented in table 3 .

Table 3. Microbiological indicators of wheat, rye and barley samples (0-0 - permissible level according to TR CU 021/2011)

\begin{tabular}{|l|c|c|c|c|}
\hline \multirow{2}{*}{ Samples } & \multicolumn{4}{|c|}{ Defined indicators } \\
\cline { 2 - 5 } & QMAFAnM, CFU/g & Colibacillus group & Mold, CFU/g & Yeast, CFU/g \\
\hline $0-0$ & $<5,0 \times 10^{3}$ & not allowed in $0.1 \mathrm{~g}$ & $<50$ & $<100$ \\
\hline $\mathrm{w}-0$ & $1,6 \times 10^{5}$ & detected in $0.01 \mathrm{~g}$ & 220 & 30 \\
\hline $\mathrm{w}-1$ & $0,8 \times 10^{2}$ & not detected in $0.1 \mathrm{~g}$ & 30 & not detected \\
\hline $\mathrm{r}-0$ & $>5,0 \times 10^{4}$ & detected in $0.01 \mathrm{~g}$ & $>1000$ & $<10$ \\
\hline $\mathrm{r}-1$ & $5,0 \times 10^{3}$ & not detected in $0.1 \mathrm{~g}$ & 30 & $<10$ \\
\hline $\mathrm{b}-0$ & $>5,0 \times 10^{4}$ & detected in $0.01 \mathrm{~g}$ & 100 & 30 \\
\hline $\mathrm{b}-1$ & $4,4 \times 10^{3}$ & not detected in $0.1 \mathrm{~g}$ & 30 & $<10$ \\
\hline
\end{tabular}

Indicators of wheat, rye and barley meet the permissible level. This allows grain to be processed with the same plant parameters to save time and resources. 


\section{Conclusions}

You can resort to various methods to improve the competitiveness of the enterprise. One of them is the use of modern technologies in the preparation of dishes and products. The trend towards healthy eating also continues. The use of crushed sprouted grains in cooking will diversify the range of products and attract a new audience.

But do not forget about the quality and safety of products in pursuit of trends. Using processing cold plasma radiation would ensure safety raw materials used in the preparation of food products and without loss of quality.

It was found that the use of CPR in the processing of oats, wheat, rye and barley grains for germination makes it possible to reduce microbiological parameters to an acceptable level. The optimal radiation parameters are set to voltage $10 \mathrm{kV}$, frequency $50 \mathrm{~Hz}$ and exposure $10 \mathrm{~min}$. These parameters are suitable for the four types of grain studied.

\section{Acknowledgements}

Special thanks to the departments of "Food and Biotechnology" and "Optoinformatics" of the South Ural State University for their help in research on the processing of grain with cold plasma radiation.

\section{References}

1. N.V. Leiberova, O.V. Chugunova, N.V. Zavorokhina, Economy of the region, 4, 142 (2011)

2. A. Vyatkin, O.Chugunova, A. Arisov, Proceedings of the 2nd International Scientific conference on New Industrialization: Global, national, regional dimension, 568 (2018)

3. E.P. Kalinin, I.V. Mozzherina, D.I. Boyarintsev et al., Strategy for the development of mass sports work with students: mat. II International scientific-practical. conf., 82 (2018)

4. Yu.R. Rakhmatullina, A.A. Andreeva, V.V. Kirdyashkin, Bread products, 3, 50 (2012)

5. M. Morales de la Peña, J. Welti-Chanes, O. Martín-Belloso,Current opinion in food science, 30, 1 (2019).

6. Y. Kretova, L. Tsirulnichenko, N. Naumenko, N. Popova, I. Kalinina,Agronomy research, 5, 5, 2079 (2018).

7. I. Kalinina, N. Naumenko, R. Fatkullin, IOP Conference Series: Earth and Environmental Science, 272, 1 (2018).

8. N.V. Naumenko, I. Yu. Potoroko, N.V. Popova, I.V. Kalinin, B.K. Proceedings of the Voronezh State University of Engineering Technologies, 81, 4 (82), 110 (2019).

9. N.V. Naumenko, Scientific and practical substantiation of technological methods for reducing the risks of contamination and food losses in the processing of wheat grain: dis. ... Dr. Tech. sciences(05.18.15) (2020) 